Article

\title{
Genetic Transformation and siRNA-Mediated Gene Silencing for Aphid Resistance in Tomato
}

\author{
Mohammad Faisal ${ }^{1, *} \mathbb{C}$, Eslam M. Abdel-Salam ${ }^{1}{ }^{\mathbb{D}}$, Abdulrahman A. Alatar ${ }^{1}$, Quaiser Saquib ${ }^{2}$, \\ Hend A. Alwathnani ${ }^{1}$ and Tomas Canto ${ }^{3}$ \\ 1 Department of Botany \& Microbiology, College of Science, King Saud University, P.O. Box 2455, Riyadh \\ 11451, Kingdom of Saudi Arabia; eabdelsalam@ksu.edu.sa (E.M.A.-S.); aalatar@ksu.edu.sa (A.A.A.); \\ wathnan@ksu.edu.sa (H.A.A.) \\ 2 Zoology Department, College of Science, King Saud University, P.O. Box 2455, Riyadh 11451, Kingdom of \\ Saudi Arabia; quaisersaquib0@gmail.com \\ 3 Centro de Investigaciones Biológicas (CIB, CSIC), Ramiro de Maeztu 9, 28040 Madrid, Spain; \\ tomas.canto@cib.csic.es \\ * Correspondence: faisalm15@yahoo.com; Tel.: +966-11-4675877
}

Received: 3 November 2019; Accepted: 12 December 2019; Published: 17 December 2019

\begin{abstract}
We explored the ability of RNA interference (RNAi) to silence the Acetylcholinesterase 1 (Ace 1) gene in aphid Myzus persicae and developed transgenic tomato plants resistant to aphid infestation. Three plasmid constructs, T-449: a single Ace 1 fragment (forward orientation), T-452: two Ace 1 fragments (reverse and forward orientations), and T455: a single inverted Ace 1 fragment, were developed and transformed into two tomato cultivars, Jamila and Tomaland. PCR, northern blotting, and small interfering RNAs (siRNA) analysis were performed to validate the success of Agrobacterium-mediated transformation. The efficiency of transformation was highest for the T-452 construct. In vivo effects of the transformed constructs were confirmed in feeding experiments, and there was significant downregulation of the Ace 1 gene. In addition, an aphid challenge assay was conducted to investigate the siRNA-mediated silencing of the target gene (Ace 1) in the inhibition of fecundity in M. persicae. We found that the plants that were transformed with the T-452 vector had $37.5 \%$ and $26.4 \%$ lower fecundity at $27^{\circ} \mathrm{C}$ in the Jamila and Tomaland, respectively. Our results strongly indicated that the plant-mediated silencing of aphid-RNA might be a robust and effective approach for developing pest and disease resistant in plants.
\end{abstract}

Keywords: Agrobacterium tumefaciens; genetic transformation; horticulture crop; northern blotting; RNAi

\section{Introduction}

Tomato (Solanum lycopersicum L.; Solanaceae) is considered to be one of the most important vegetable crops in the world, as it ranks first in terms of production and cultivation area. According to the FAOSTAT database (http://www.fao.org/faostat/en/), the total harvested area of tomatoes reached 4.8 million ha, with total production exceeding 182 million tons in 2017. As a rich source of vitamins (especially A and C), minerals, amino acids, and dietary fibers, the tomato is also considered as one of the most important nutritive crops and is of great economic value [1].

Tomato cultivation suffers from serious losses due to infestation by insects and pests and the diseases that they transmit. Myzus persicae (aphids), sap-sucking bugs of the order Hemiptera, has been considered a significant crop pest in terms of direct feeding damage and transmission of plant infections [2]. It can bolster on over 40 distinctive plant families [3] and is capable of effectively transmitting over 100 sorts of plant viruses [4]. In the aphid, the Ace 1 gene is one of two genes coding for acetylcholinesterases (AChEs). AChEs (EC 3.1.1.7) are the main receptors of some 
pesticides, including carbamate and organophosphate insecticides. Their main function is to catalyze the hydrolysis of a few choline esters, counting acetylcholine, which basically work as neurotransmitters in insects. Hence, inhibition of $A C h E s$ leads to the obstruction of neurotransmission and death of the insects [5]. Management of insect-pest problems in the tomato is an important concern. One approach is genetic enhancement through the use of genetic engineering that offers a novel method to urge disease-resistant plants that not only display high resistance to multiple pathogen attacks but that are ecologically secure and sound. The Agrobacterium-mediated genetic transformation method has several advantages over other approaches to deal with transgenic plant production; it is fairly straightforward, easy to use, has a limited cost of equipment, and generally results in a single or low duplicate of the transgene being inserted. Because of its nutritive and economic significance, the tomato was one of the first plants to be genetically modified, which was achieved using Agrobacterium [6]. Thereafter, studies used different protocols and explants to produce genetically modified tomato plants in order to enhance the quality or develop disease resistance [7-9].

Small non-coding RNA molecules (siRNA and miRNA) are evolutionarily-conserved homology-dependent unique phenomena of gene silencing, demonstrating its vital role in genetic expression termed as RNA silencing or RNA interference "RNAi" [10]. It involves dsRNA-initiated sequence-specific degradation of cognate RNA via 21 nucleotide (nt) length effector molecules with the aid of cellular protein machinery. The silencing phenomenon results from either transcription inhibition (Transcriptional Gene Silencing; TGS) or from RNA degradation (Post-transcriptional Gene Silencing; PTGS) and has been correlated with the accumulation of siRNAs [11,12]. Transgenic plants expressing small RNA molecules designed to silence insect targeted genes gain more attention and are considered as the next generation of pest management strategies, considering their beneficial effects as compared to other chemical and biological strategies [13]. Host-induced gene silencing (HIGS) utilizing the RNA hushing mechanisms and, particularly, silencing the targets of attacking pathogens, have been effectively used in the management of plant viral diseases [14]. HIGS is a process in which the host plant is genetically transformed to produce small RNA molecules to target transcripts in insects and/or parasites. siRNA-mediated gene silencing for aphid resistance has been successfully reported in several crops, including tobacco [15-19], Arabidopsis [20,21], wheat [22], and barley [23] to reduce fecundity and parthenogenetic population of aphids. Tomatoes showed a significant fungal resistance after expressing small RNAs targeting the dicer-like transcripts of Botrytis cinerea [24]. Furthermore, tomato lines expressing short tandem targets mimicking RNAs from the miR482/2118 microRNAs family showed enhanced resistance to bacterial and oomycetes infections [25]. Viral outbreaks on crops of commercial interest are becoming increasingly common as a result of climate change and of increased global trade, both of which are capable of increasing the dispersal rate of plant viruses and their insect vectors, geographically as well as temporally during the growing season [26]. Commercial agriculture in Saudi Arabia has become a highly mechanized and technological enterprise that depends on the use of selected high quality and adapted plant varieties and supply of inputs that compensate for the agriculturally unfavorable environmental conditions for agriculture that occur throughout most of the kingdom. Viral disease outbreaks can potentially cause serious losses in yields and/or quality in densely planted monocultures.

This study aimed to develop an efficient and robust genetic transformation system in two elite tomato cultivars grown in Saudi Arabia, and assess the degree of silencing of a specific gene (Myzus persicae Ace 1 gene) in aphids, the effect of silencing on the fitness of the insect colonies, and their ability to disseminate viral disease.

\section{Materials and Methods}

\subsection{Bacterial Strain and Construct}

Agrobacterium tumefaciens strain LB4404 (ElectroMax, Invitrogen Life Technologies, Carlsbad, CA, USA) was used in the transformation experiments. Three plasmid constructs were developed and 
transfected into the bacterial strain. The Construct T-448 is a pBluescript II SK (+) vector, which is a phagemid excised from lambda ZAPII (Accession: X52324.1) [27] containing an insert between XhoI and $\mathrm{XbaI}$ sites of its polylinker corresponding to a cDNA fragment of the Acetylcholinesterase gene (Ace 1 fragment) obtained by RT-PCR from the aphid M. persicae (Figure 1). The fragment consists of nucleotides 1095 to 1677 of the published sequence with the accession number AY 147,797 [5]. Constructs T-449, T-452, and T-455 were based on the binary vector pFGC5941 (accession AY310901: phosphinothricin acetyl transferase $(B A R)$ and aminoglycoside phosphotransferase (aadA) genes [28].
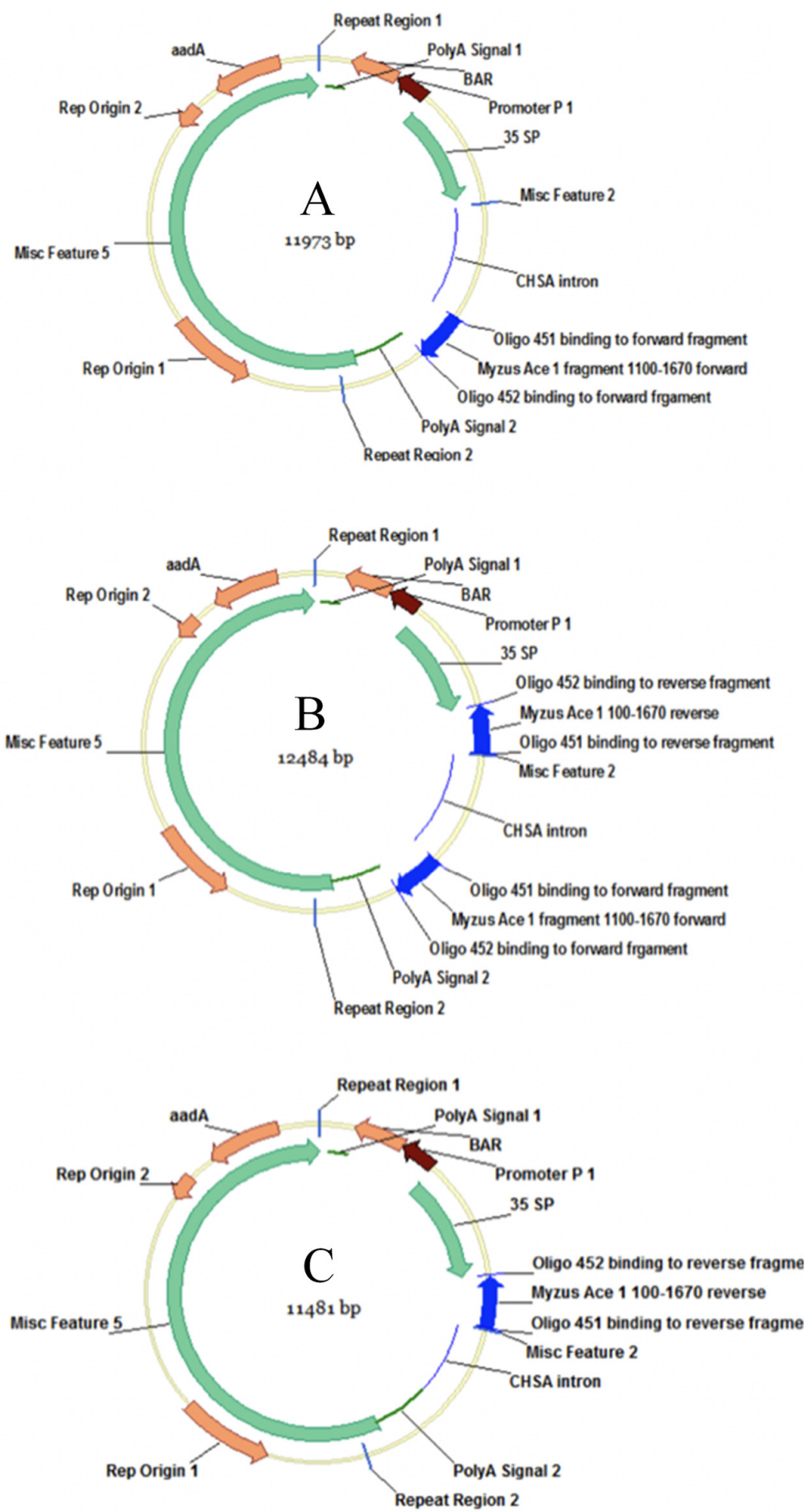

Figure 1. Schematic representation of constructs: (A) T-449: pGCS5941 binary with single Myzus persicae Ace I fragment 1100-1670; (B) T-452: pGCS5941 binary with double Myzus persicae Ace 1 fragment 1100-1670; (C) T-455: pGCS5941 binary with single inverted Myzus persicae Ace 1 fragment 1100-1670. 
Construct T-449 contains a single Ace 1 fragment in the forward orientation (Figure 1A). Construct T-452 contains two Ace 1 fragments in the reverse and forward orientations, respectively, flanking the plasmid intron sequence (Figure 1B). Construct T-455 contains a single inverted Ace 1 fragment only (Figure 1C).

\subsection{Electroporation (Transformation) and Selection of Positive Colonies}

Agrobacterium tumefaciens LB4404 was transformed with each binary vector by electroporation. Electroporation was performed in a $0.1 \mathrm{~cm}$ MicroPulser ${ }^{\mathrm{TM}}$ cuvette (Bio-Rad, Bio-Rad Laboratories Inc., Hercules, CA, USA) using a MicroPulser Electroporator (Bio-Rad) under the following conditions: $2.0 \mathrm{kV}, 200 \Omega, 25 \mu \mathrm{F}$. After electroporation, the cells were transferred to a $15 \mathrm{~mL}$ tube with $1.0 \mathrm{~mL}$ of LB medium incubated at $220 \mathrm{rpm}\left(30^{\circ} \mathrm{C}\right)$ for $3 \mathrm{~h}$ with shaking. The transformed cells were then spread on pre-warmed LB-agar plates supplemented with Kanamycin $(50 \mu \mathrm{g} / \mathrm{mL})$ and Streptomycin $(200 \mu \mathrm{g} / \mathrm{mL})$ and incubated for $48-56 \mathrm{~h}$. Colonies that had been transformed and were carrying a binary vector were grown on selective LB-agar plates and stored for co-cultivation and transformation experiments.

\subsection{Plant Materials and Explants Preparation}

Seeds of tomato cultivars Jamila and Tomaland were cleaned in running tap water for $20 \mathrm{~min}$, followed by soaking in 5\% (v/v) detergent solution for $10 \mathrm{~min}$. After thorough rinsing with sterile ultrapure pure $\mathrm{H}_{2} \mathrm{O}$, the seeds were surface disinfected with $2.5 \%(\mathrm{v} / \mathrm{v})$ sodium hypochlorite (Clorox Co., Jeddah, Saudi Arabia) for $10 \mathrm{~min}$ and then rinsed 4-5 times with sterile ultrapure $\mathrm{H}_{2} \mathrm{O}$ to remove the disinfectant. The seeds were then germinated on sterile cotton moistened with sterile half-strength Murashige and Skoog (MS) medium [29].

In our preliminary in vitro culture experiments, considerable efforts were devoted to optimizing the most suitable conditions for plant regeneration, and cotyledonary leaf explants were found to be more responsive explants [1]. Therefore, cotyledonary leaves (CL) from aseptic seedlings that were 8-10 d old were used as explants. The leaf discs were incubated on in vitro regeneration medium for 2 days at a $24^{\circ} \mathrm{C}$ temperature in a growth chamber (Conviron Adaptis, Winnipeg, MB, Canada) before co-cultivation with Agrobacterium. Proper care was taken while placing leaf discs on the medium so that the dorsal surface was always in contact with the media.

\subsection{Co-Cultivation of CL Explants with Agrobacterium}

Agrobacterium-containing constructs were grown in LB with Kanamycin $(50 \mu \mathrm{g} / \mathrm{mL})$ and Streptomycin $(200 \mu \mathrm{g} / \mathrm{mL})$ at $28^{\circ} \mathrm{C}$ and $200 \mathrm{rpm}$ overnight. The culture $(50 \mathrm{~mL})$ was then pelleted at $4{ }^{\circ} \mathrm{C}$ temperature at $6000 \mathrm{rpm}$ for $10 \mathrm{~min}$. Leaf discs were transferred into approximately $20 \mathrm{~mL}$ autoclaved MS liquid (MS salt without agar) and $200 \mu \mathrm{L}$ of the culture incubated for 20 min with occasional slow shaking to induce proper infection. The leaf discs were then transferred to another plate and dried using sterile blotting paper. After blot drying, the leaf discs were transferred onto the selective medium MS + BA $(5.0 \mu \mathrm{M})+$ IBA $(2.5 \mu \mathrm{M})+$ Kinetin $(10.0 \mu \mathrm{M})+$ Augmentin $(200 \mu \mathrm{g} / \mathrm{mL})+$ Kanamycin $(50 \mu \mathrm{g} / \mathrm{mL})$ and incubated in dark for proper transfer.

\subsection{Selection and Regeneration of Plantlets}

After $48 \mathrm{~h}$ of co-cultivation, the leaf discs were transferred onto selection medium. They were then aseptically relocated onto shoot-regeneration medium for multiplication and plant regeneration. The culture were maintained in a growth chamber under $50 \mu \mathrm{mol} \mathrm{m}^{-2} \mathrm{~s}^{-1}$ light provided by cool white LEDs for a photoperiod of $16 \mathrm{~h}$ at $22 \pm 2{ }^{\circ} \mathrm{C}$, and the regenerated buds were regularly sub-cultured onto the freshly prepared media. 


\subsection{Rooting and Establishment of Transgenic Plants}

For rooting, the regenerated shoots were individually transferred to $\frac{1}{2} \mathrm{MS}$ medium containing $0.5 \mu \mathrm{M}$ indole-3-butyric acid (IBA). The rooted transgenic shoots were transferred to pots containing sterile potting soil (Planta Guard) and kept in a growth chamber at $22 \pm 2{ }^{\circ} \mathrm{C}$ with diffuse light of $50 \mu \mathrm{mol} \mathrm{m}{ }^{-2} \mathrm{~s}^{-1}$ for a photoperiod $16 \mathrm{~h}$ for acclimation. The in vitro generated transgenic plants (T0) were used for PCR characterization and northern blotting, and the homozygous seeds (T1) were further selected and used for aphid challenge assay and qRT-PCR analysis of the target gene.

\subsection{Characterization of Transgenic Plants by PCR Analysis}

DNA was isolated from $300 \mathrm{mg}$ of fresh leaf tissues from the transformed plants (T0) following the method of Doyle and Doyle [30], and the isolated DNA was quantified using a NanoDrop ${ }^{\text {TM }} 200 \mathrm{c}$ spectrophotometer (Thermo Scientific ${ }^{\mathrm{TM}}$, Waltham, MA, USA). PCR reactions were carried out in a thermocycler (T-100, Bio-Rad Laboratories Inc., Hercules, CA, USA) in a $50 \mu \mathrm{L}$ of reaction mixture containing $25 \mathrm{ng}$ of DNA, Tris-SO $\mathrm{SO}_{4}(60 \mathrm{mM})(\mathrm{pH} 8.9),\left(\mathrm{NH}_{4}\right)_{2} \mathrm{SO}_{4}(18 \mathrm{mM}), \mathrm{MgSO}_{4}(2 \mathrm{mM}), \mathrm{dNTP}$ mix $(250 \mathrm{nmol})$, primer $(1 \mu \mathrm{M}$ of each), and $5 \mathrm{U}$ of Taq DNA polymerase (Fermentas, Waltham, MA, USA). Primer pairs used for the confirmation of BAR genes as follows; GGTCTGCACCATCGTCAACC-F and CTGCCAGAAACCCACGTCAT-R. The reaction mixture was amplified at $95^{\circ} \mathrm{C}(5 \mathrm{~min})$, followed by 35 cycles of $95^{\circ} \mathrm{C}$ for $1 \mathrm{~min}, 55^{\circ} \mathrm{C}$ for $1 \mathrm{~min}$, and $72^{\circ} \mathrm{C}$ for $1 \mathrm{~min}$, followed by a final extension of $5 \mathrm{~min}$ at $72^{\circ} \mathrm{C}$. The amplified products were electrophorized at $60 \mathrm{~V}$ for $1 \mathrm{~h}$ in $1 \times$ TBE buffer using $1 \%$ agarose gels and stained with ethidium bromide $(0.5 \mu \mathrm{g} / \mathrm{mL})$ and photographed using a Gel Documentation System (G-Box, Syngene, Cambridge, UK). The housekeeping gene GAPDH was run as control to ensure the equal loading of samples.

\subsection{Characterization of Transgenic Plants by Northern Blotting}

A total of $100 \mathrm{mg}$ of leaf tissues collected from T0 plants were crushed in liquid nitrogen, and total RNAs were extracted by adding $400 \mu \mathrm{L}$ of $0.1 \mathrm{M}$ Tris- $\mathrm{HCl}$ (pH 8.0), $10 \mathrm{mM}$ EDTA, $0.1 \mathrm{M} \mathrm{LiCl}$, 2-mercaptoethanol (1\%), and SDS (1\%) at room temperature. For northern blotting, $400 \mu \mathrm{L}$ of extract was mixed with an equal volume of phenol/chloroform and vortexed for $10 \mathrm{~min}$. Samples were centrifuged at 12,000 rpm for $10 \mathrm{~min}$, and supernatants were carefully collected and re-extracted with an equal volume of phenol/chloroform followed by centrifugation at 12,000 rpm for $5 \mathrm{~min}$. Supernatants were then aspirated without taking debris from the interface. Ethanol precipitation of supernatants were performed by adding $7.5 \mu \mathrm{L}$ of sodium acetate $(3 \mathrm{M})$ and 3 volumes of absolute ethanol. The solution was kept at $-80{ }^{\circ} \mathrm{C}$ for $30 \mathrm{~min}$, followed by centrifugation and washing with ethanol $(70 \% \mathrm{v} / \mathrm{v})$. The pellets were air dried and finally resuspended in $100 \mu \mathrm{L}$ of autoclaved MilliQ water, and frozen until use. Samples $(30 \mu \mathrm{L})$ were separated on polyacrylamide gels $(15 \%)$ containing urea $(7 \mathrm{M})$. Before transfer, equal loading of samples was confirmed by staining the gel with ethidium bromide. The gel was transferred to Amersham Hybond-N+ membranes (GE Healthcare, Buckinghamshire, UK) using $0.5 \times$ TBE buffer at $300 \mathrm{~mA}$ for $40 \mathrm{~min}$. The wet membranes were cross-linked by UV exposure. The probe was obtained using T3 RNA polymerase after linearization of the pSK-Achl (T448) fragment with the restriction enzyme BamHI. Blots were prehybridized and hybridized with a DNA probe (digoxigenin-11-UTP) prepared following the manufacturer's instructions (DIG Northern Starter Kit, Roche Diagnostics GmbH, Mannheim, Germany).

\section{9. qRT-PCR Analysis of Ace 1 Expression in Aphids Fed on Transgenic Plants}

Transcriptional variation of in M. persicae Acetylcholinesterase 1 gene (MpAce 1) level was analyzed using qRT-PCR. Aphids were fed on transgenic plants (T1) to analyze their MpAce 1 expression. After 14 days, 5 adult aphids were selected from the tomato plants for the aphid challenge assay. Total RNA was isolated from selected aphids using Triazole reagent followed by treatment with a TURBO DNA free kit (Ambion Inc., Austin, TX, USA). One step RT-qPCR was performed in a $15 \mu \mathrm{L}$ 
of reaction mixture containing, SYBER Green $(7.5 \mu \mathrm{L})$, primer $(5 \mu \mathrm{M})$ of each primer of target gene (CCGTTGGGACAATACAAACC-F, GGATTCCACATTGTAGCAC-R), DTT (0.15 $\mu$ L of $100 \mathrm{mM})$, RT Mix $(0.75 \mu \mathrm{L})$, RNAase-free water $(1.8 \mu \mathrm{L})$, RNA $(3 \mu \mathrm{L})$ (approximately $10 \mathrm{ng} / \mu \mathrm{L})$. Expressional analysis was performed using a Rotor-Gene Q thermal cycler (Qiagen, Venlo, Limburg, The Netherlands) with the following parameters; $50^{\circ} \mathrm{C}$ for $10 \mathrm{~min}, 95^{\circ} \mathrm{C}$ for $3 \mathrm{~min}, 40$ cycles of $95^{\circ} \mathrm{C}$ for $10 \mathrm{~s}$, and $60{ }^{\circ} \mathrm{C}$ for $20 \mathrm{~s}$, and a final ramp from $60{ }^{\circ} \mathrm{C}$ to $95^{\circ} \mathrm{C}$ rising $1{ }^{\circ} \mathrm{C}$ every $5 \mathrm{~s}$. Reactions were performed in triplicate for all samples with duplicate replicates in each run. Relative expression of MpAce 1 was analyzed using the $2^{-\Delta \Delta C T}$ method of the Rotor-Gene Q Series Software (Qiagen). Statistical analyses were performed using SPSS statistics software, Version 24 (SPSS Inc. Chicago, IL, USA). The housekeeping GAPDH gene was used as an internal control.

\subsection{Aphid Challenge Assay}

To screen the insect resistance against transgenic tomato plants and determine the effect of varying temperatures on aphid fitness, 5 plants (T1) from each construct (T-455, T-452, and T-449) were grown in individual pots at 2 different temperatures $\left(22^{\circ} \mathrm{C}\right.$ and $\left.27^{\circ} \mathrm{C}\right)$. With the help of writing brush, seedlings at the 5-leaf stage were inoculated with 5 adult aphids. After $7 \mathrm{~d}$, all adults were removed, and 5 two-day-old nymphs were left on leaves of each line to grow for 2 weeks. After $14 \mathrm{~d}$, the total number of the aphids grown on seedling leaves was counted. Their numbers were recorded as the fecundity of 5 nymphs. Empty vector transgenic plants and untransformed tomato plants were inoculated in parallel as negative controls.

\subsection{Data Analysis}

For tomato transformation, 50 explants were used for each construct, and the experiments were performed in duplicate. The data for plant regeneration was recorded after 8 weeks and statistically evaluated using SPSS, and the values were compared using a multiple range test (DMRT) at 5\% significance. Percent transformation efficiencies (TE) were calculated on the basis of co-cultivated explants producing transgenic shoots on selective media using the following equation:

$$
T E(\%)=\frac{\text { Number of transgenic plants regenrated }}{\text { Total number of explants used for transformation }} \times 100 \%
$$

For the molecular data, differences in expression were determined by using Dunnett's multiple comparison test (Sigma Plot 11.0; Systat Software Inc., San Jose, CA, USA) with a significance threshold of $p<0.05$ unless otherwise stated. ${ }^{*} p<0.05,{ }^{* *} p<0.01$ verses normal plant (NM).

\section{Results and Discussion}

\subsection{Generation of Transgenic Plants and PCR Confirmation}

Schematic representation of the tomato transformation is depicted in Figure 2. A total of 100 CL explants of cultivars Jamila and Tomaland derived from 8-10 d old aseptic seedlings were co-cultivated with Agrobacterium carrying the constructs T-449, T-452, and T-455. Twenty CL explants were cultured for regeneration as a control. The co-cultivated explants were cultured on selective media MS + BA $(5.0 \mu \mathrm{M})+$ IBA $(2.5 \mu \mathrm{M})+$ Kinetin $(10.0 \mu \mathrm{M})+$ Augmentin $(200 \mu \mathrm{g} / \mathrm{mL})+$ Kanamycin $(50 \mu \mathrm{g} / \mathrm{mL})$ (Figure 3A). After 2 weeks, the co-cultivated explants were selected and transferred onto the medium supplemented with BA $(5.0 \mu \mathrm{M})+$ IBA $(2.5 \mu \mathrm{M})+$ Kinetin $(10.0 \mu \mathrm{M})$ for shoot regeneration. Shoot buds were observed two weeks after transfer onto a shoot induction medium (Figure 3B). The frequency of co-cultivated explants producing shoots differed widely between the genotypes and constructs. As shown in Table 1, varying transformation efficiencies were obtained in both the cultivars. Such variations can be caused by tomato genotypes and the use of different constructs, which can be understood by $63 \%$ transformation efficiency with T- 452 in Jamila, while it was approximately $58 \%$ in cv. Tomaland (Table 1). In addition, the lowest efficiency of $40 \%$ was found in cultivar Tomaland by 
using the binary vector T-449. The results obtained were in agreement with earlier findings of genetic manipulation in tomato, suggesting differences of transformation efficiency with various plasmid constructs [31,32]. About $90 \%$ of the transgenic plants survived to ex vitro condition and did not show any immediate detectable variation with respect to morphology or growth characteristics (Figure 3D). Further, confirmation of transgenic plants was carried out using PCR analysis. The PCR bands in corresponding gels unequivocally demonstrated the successful transformation of different constructs in tomato plants (Figure 3E).

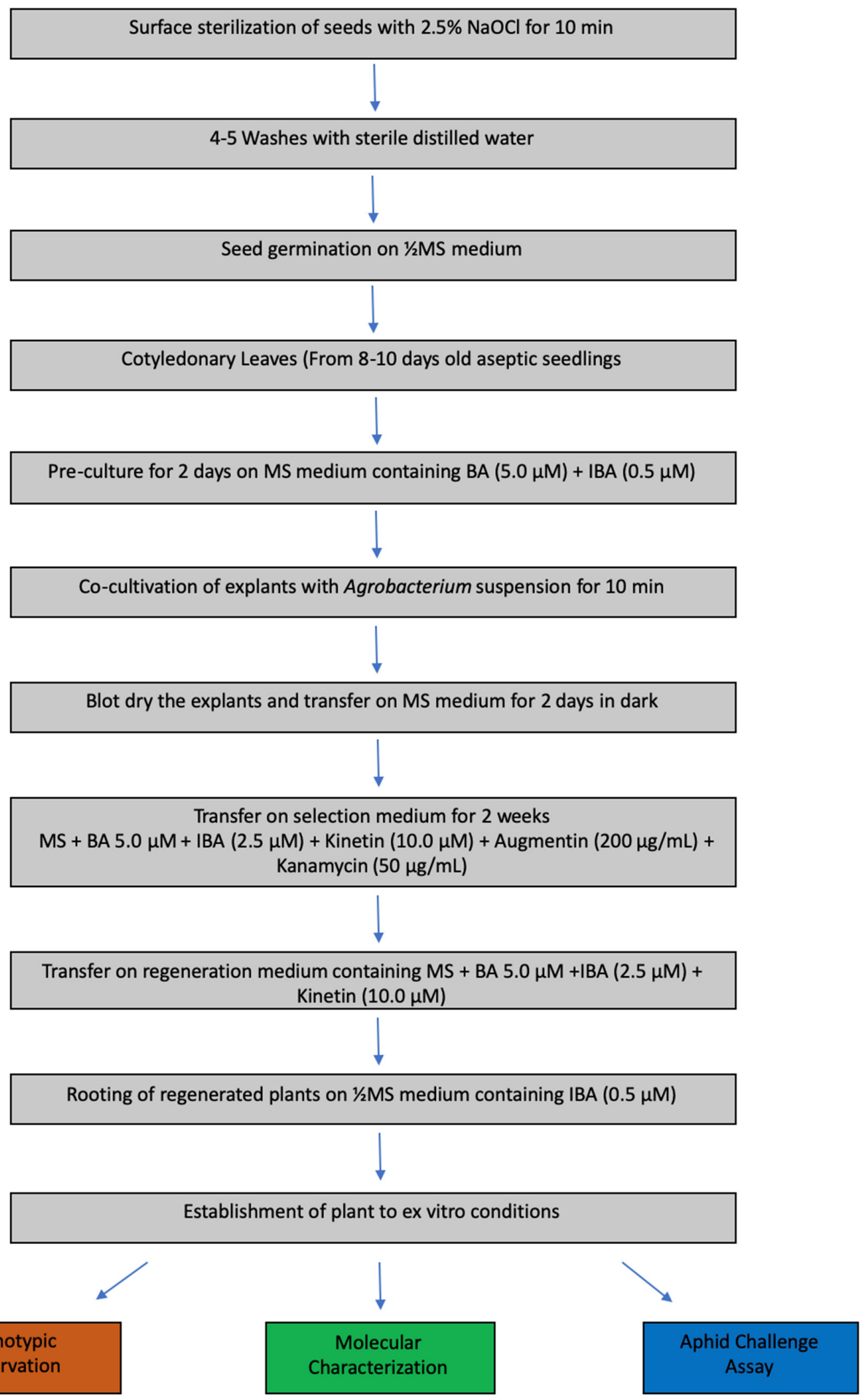

Figure 2. Schematic representation of genetic transformation in tomato. 

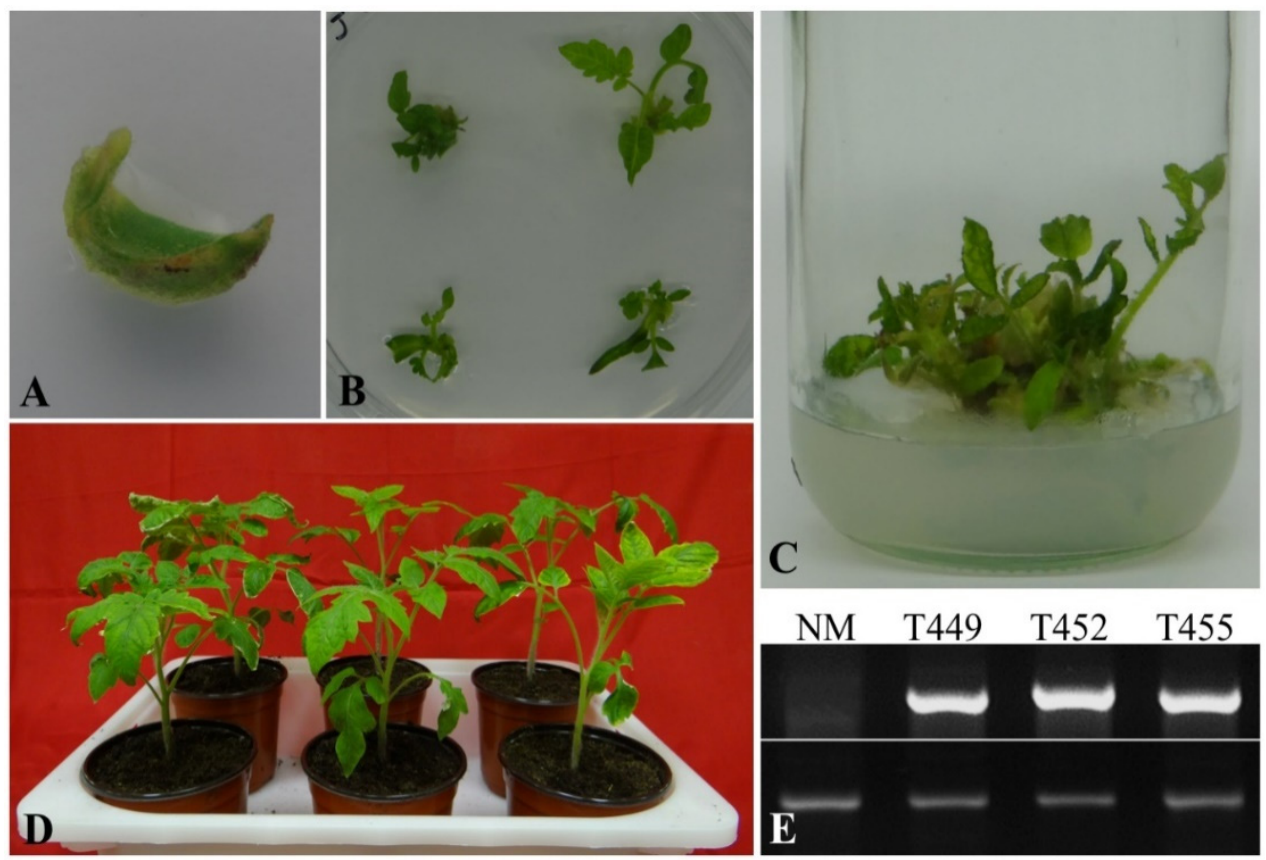

Figure 3. Genetic transformation in tomato (A) cotyledonary leaves (CL) explants cultured on selective media after co-cultivation; (B) induction of multiple shoots on regeneration medium; (C) proliferation of shoots on regeneration medium; (D) regenerated transgenic plants established to ex vitro conditions; (E) PCR confirmation of transgenic plants generation with the T-449, T-452, and T-455 constructs in a $1 \%$ agarose gel. The housekeeping gene GAPDH was run as control to ensure loading of samples. NM refers to control.

Table 1. Transformation efficiency of different constructs in tomato cultivars Jamila and Tomaland.

\begin{tabular}{cccccc}
\hline \multirow{2}{*}{$\begin{array}{c}\text { Plasmid } \\
\text { Constructs }\end{array}$} & $\begin{array}{c}\text { Number of Explants } \\
\text { Co-Cultivated }\end{array}$ & \multicolumn{2}{c}{$\begin{array}{c}\text { Mean Number of } \\
\text { Explants Produce Shoots }\end{array}$} & \multicolumn{2}{c}{$\begin{array}{c}\text { Mean Transformation } \\
\text { Efficiency (\%) }\end{array}$} \\
\cline { 3 - 6 } & 100 & Jamila & Tomaland & Jamila & Tomaland \\
\hline T-449 & 100 & $45^{\mathrm{b}}$ & $40^{\mathrm{b}}$ & $45^{\mathrm{b}}$ & $40^{\mathrm{b}}$ \\
\hline $\mathrm{T}-452$ & 100 & $63^{\mathrm{a}}$ & $58^{\mathrm{a}}$ & $63^{\mathrm{a}}$ & $58^{\mathrm{a}}$ \\
\hline $\mathrm{T}-455$ & $52^{\mathrm{c}}$ & $49^{\mathrm{c}}$ & $52^{\mathrm{c}}$ & $49^{\mathrm{c}}$ \\
\hline
\end{tabular}

${ }^{1}$ Data represent the average of two independent experiments. Values denoted the same letters are not significantly different according to Duncan's multiple range test (DMRT) at the $5 \%$ level.

\subsection{Northern Blotting of Transgenic Plants}

The presence of siRNA produced in independent lines of constructs T-455, T-452, and T-449 in transgenic tomato cultivars Jamila and Tomaland was confirmed by northern blot analysis. The chemiluminescence analysis of northern blots revealed the abundance of siRNAs in T-452 and T-455, while the abundance was less for T-449 (Figure 4). The northern data conforms with the previous study detecting siRNAs targeting the MpAChE2 gene of Myzus persicae in tobacco [17]. Also, our data is in agreement with RNA dot blot assay for siRNA detection of the AChE gene in whitefly [33]. Additionally, the data is also supported by the expression of siRNA in A. thaliana transgenic lines targeting the $\mathrm{MpC002}$ and Rack-1 [16]. 


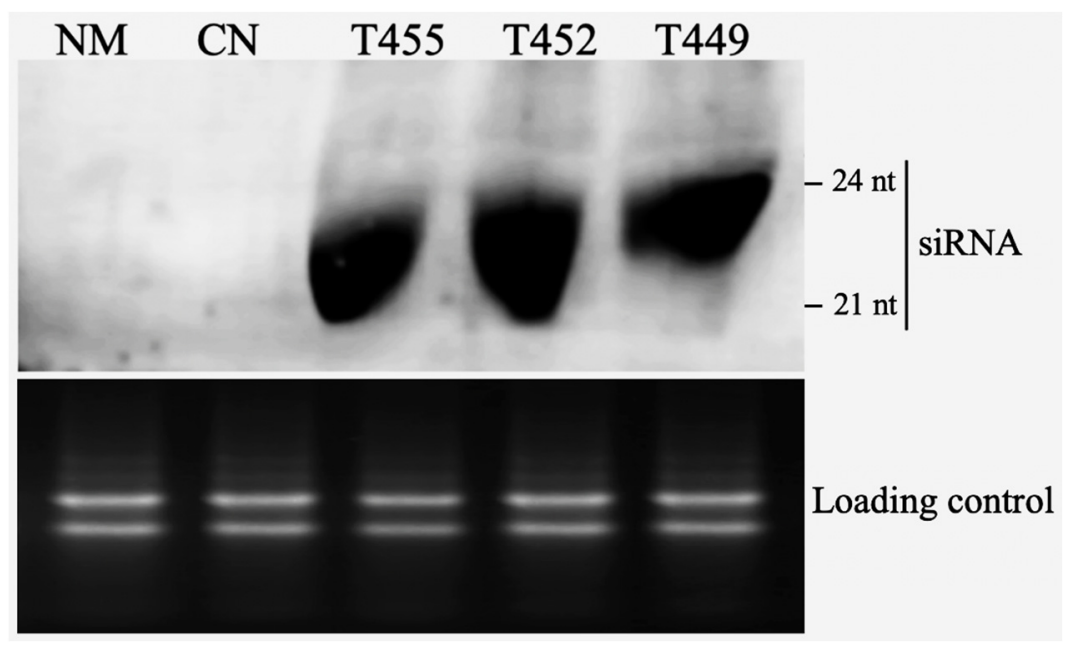

Figure 4. Northern blot detection of Ace 1 siRNAs in transgenic plants with Ace 1 specific probe. NM= normal plant; $\mathrm{CN}$ = plant with empty vector. Total RNA stained with ethidium bromide serve as the loading control.

\subsection{Transcriptional Analysis of Aphids Feeding on Transgenic Tomato Plants}

qRT-PCR data revealed that the expression levels of the target gene (Ace 1) decreased in aphids fed on either cultivars of transgenic plants, as compared to those fed on normal plants and on plants with an empty vector (Figure 5). The maximum downregulation of Ace 1 in aphids fed on construct T-452 (double insert) was found to be significant, followed by construct T-455 (inverted insert) in both cultivars. Comparatively, aphids that fed on plants with the T-449 construct did not exhibit significant downregulation of Ace 1. The higher expression level and stem stability of the siRNA and the specificity to the target may be contributing factors to these results [17]. These results are similar to those observed in microinjection and artificial feeding of siRNAs to insects. For example, chemically synthesized siRNAs resulted in Ace 1 gene downregulation with high mortality, in addition to substantial growth inhibition of survivor larvae in Plutella xylostella [34] and Helicoverpa armigera [35]. Moreover, lower gene expression of the target gene in tomato plants was corroborated with findings of Malik, Raza, Amin, Scheffler, Scheffler, Brown, and Mansoor [33] in which whiteflies that fed on tobacco plants exhibited a significant knockdown of Ache and EcR genes.
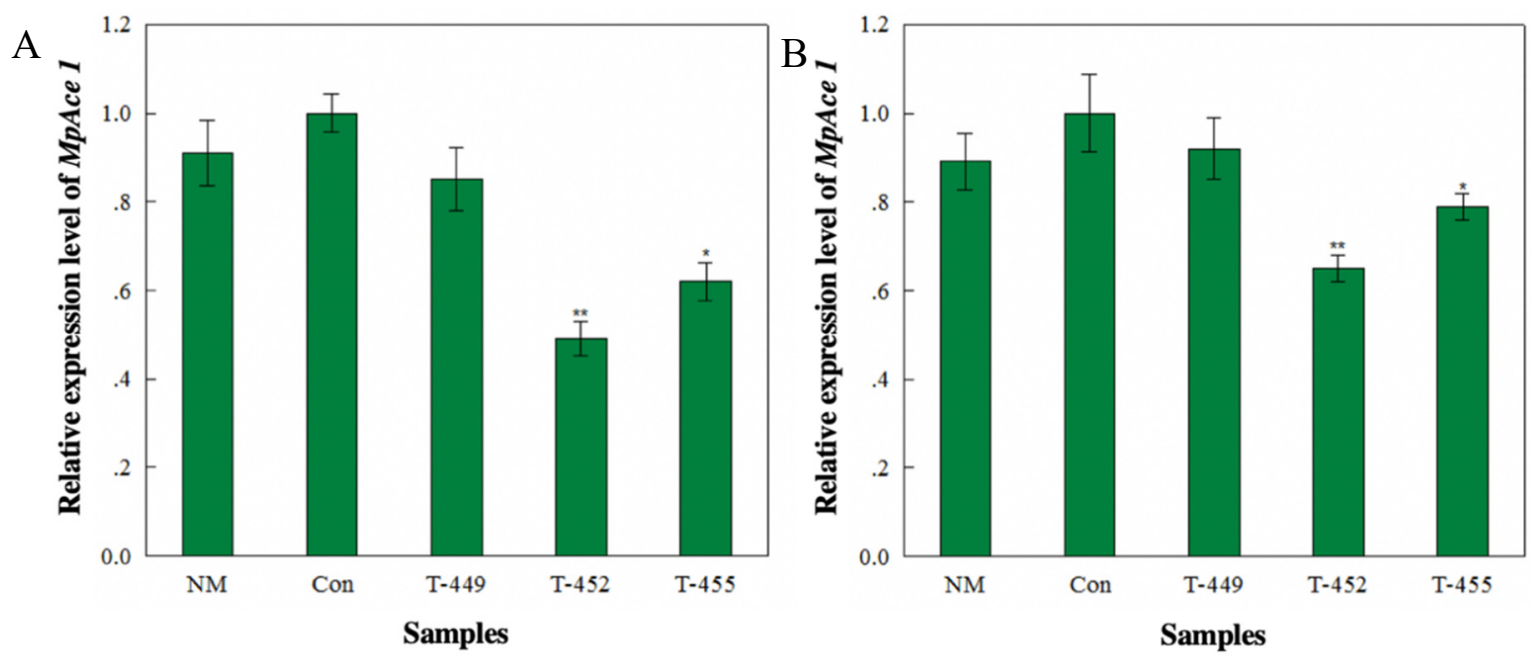

Figure 5. Knockdown of Myzus persicae Acetylcholinesterase 1 (Mp Ace 1) expression in aphids that fed on tomato cultivars Jamila (A) and Tomaland (B). NM refers to untreated plants and Con to plants transfected with an empty vector. Each histogram represents mean \pm S.E of three replicates where * denotes significantly different expression to that of NM at $p<0.05$ and ${ }^{* *}$ at $p<0.01$. 


\subsection{Aphid Resistance Against Transgenic Tomatoes}

An aphid challenge assay was conducted to investigate the plant-mediated silencing of the target gene (Ace 1) on the fecundity of M. persicae. Three independent lines of both of the cultivars were transformed with T-449, T-452, and T-455 constructs and were tested at optimal $\left(22{ }^{\circ} \mathrm{C}\right)$ and high $\left(27^{\circ} \mathrm{C}\right)$ temperatures. Five individual aphids were caged on transgenic plants (Figure 6), and their reproductive capacity was monitored and compared to the normal and control (with empty vector) plants. Fecundity data showed that the cultivars Jamila and Tomaland transformed with the T-452 (double hair loop) constructs exhibited a significant reduction in the number of aphids nymphs produced per adult by $34.2 \%$ and $26.5 \%$ at $22{ }^{\circ} \mathrm{C}$, respectively (Figure 7 ). Interestingly, at high temperature $\left(27^{\circ} \mathrm{C}\right)$ the cultivars Jamila and Tomaland transformed with the T-452 construct showed a $37.5 \%$ and $26.4 \%$ decline in nymph production, respectively. Comparatively, cultivars Jamila and Tomaland transformed with vector T-455 reduced the nymph production by only $23.6 \%$ and $20 \%$ at $22{ }^{\circ} \mathrm{C}$ respectively. Higher temperature resulted in a decline of $23.5 \%$ in nymph production in T-455 transgenic plants (Figure 7). However, plants transformed with the T-449 (direct insert) construct did not affect the number of nymphs produced at either temperature.

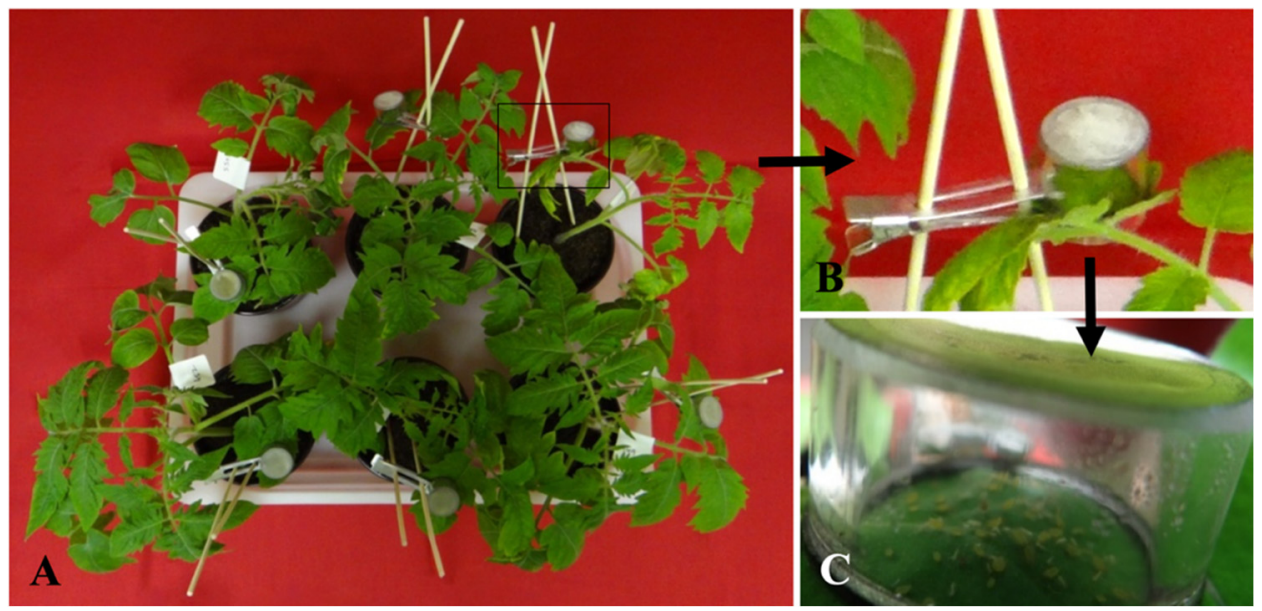

Figure 6. (A) In vivo bioassay (Aphid fitness test) of T1 transgenic plants with aphids. (B,C) Enlarged views of the inset showing aphid colonies.
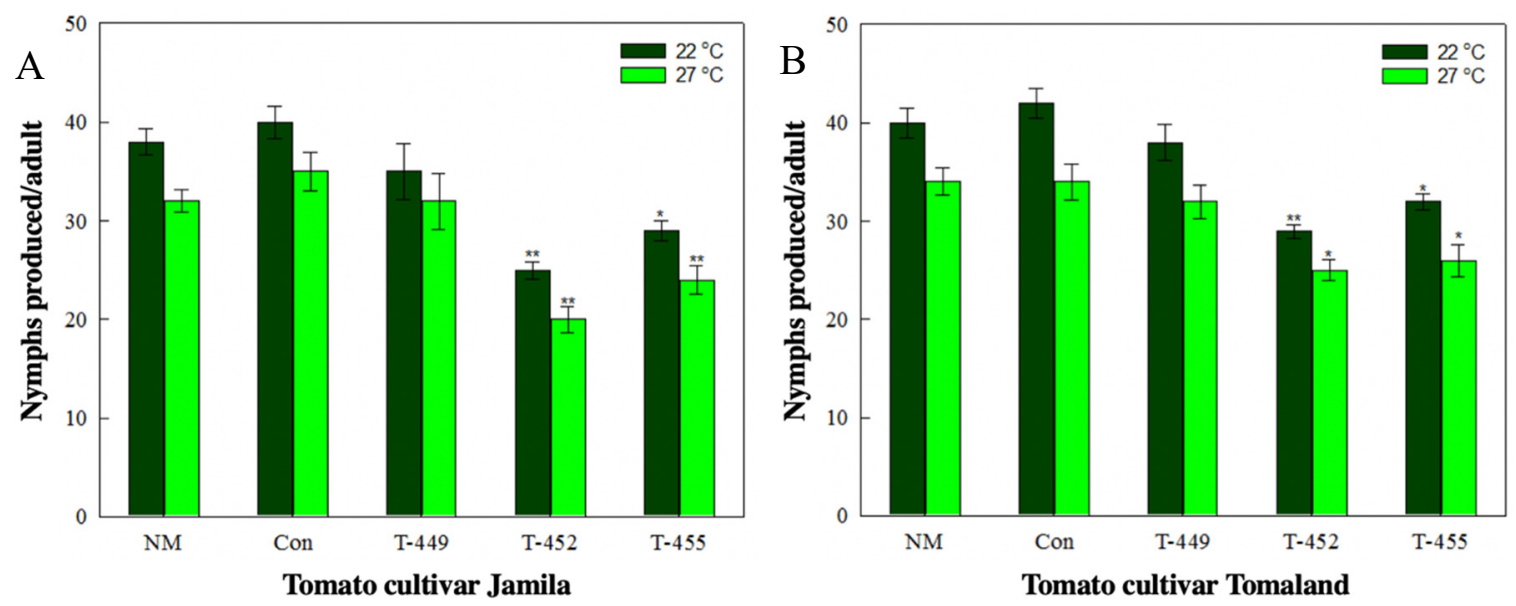

Figure 7. Effect of various constructs (T-449, T-452, and T-455) on the fecundity of aphid's nymphs at different temperatures feeding on tomato cultivars Jamila (A) and Tomaland (B) NM refers to untreated plants and Con to plants transfected with an empty vector. Each histogram represents mean \pm SE of three replicates, where * denotes significantly different expression to that of the NM treatment at $p<$ 0.05 , and ${ }^{* *}$ at $p<0.01$. 
These temperatures $\left(22\right.$ and $27^{\circ} \mathrm{C}$ ) were selected due to aphids being unlikely to survive or produce nymphs at temperatures above $30{ }^{\circ} \mathrm{C}$ [36]. Insects are ectotherms, and temperature variations play a critical role in its survival, distribution, and population dynamics $[37,38]$. Hence, understanding the effect of temperature variation on an individual's performance and the plastic responses of populations to different temperatures is critical [39]. We selected two temperatures for study because the extreme climatic conditions (heat waves and daily fluctuations) of Saudi Arabia can impact aphids in various ways, including reduced fecundity reduction and population growth, slow development, community structure, and interruption to trophic cascades [40-43]. Aphids are more sensitive to acute changes in temperature, making them a suitable test organism for our study [40]. Aphids have been mainly controlled by the application of several classes of pesticides, including neonicotinoids, organophosphates, pyrethroids, and carbamates. However, their application has lost effectiveness, toxicological effects on non-target organisms have been revealed, and severe threats to the environment have been exposed. Our molecular data (qPCR and northern blotting) on transgenic tomato showed successful expression of siRNA targeting of the Ace 1 gene in aphids. Feeding on transgenic plants exhibited a significant reduction in nymphs' production compared to aphids that fed on non-transgenic control plants. Such declines can easily be understood with consideration of the downregulation of the target genes (MpAce 1) in aphids that fed on plants producing siRNA. Reduction fecundity in aphids feeding on transgenic plants is in line with previous reports exhibiting the fall of the whitefly population when fed on transgenic tobacco plants $[17,33]$. The response of insects to extreme environmental conditions relies on a combination of different factors, such as changes in membrane structure and osmolyte compounds and molecular processes (gene expression, heat shock proteins, and enzymes), to survive and recover from unfavorable conditions [44]. However, the above molecular changes warrant an in-depth study to establish a positive role of siRNA in reducing aphid fecundity at high temperatures.

\section{Conclusions}

In conclusion, a robust Agrobacterium-mediated genetic transformation system was developed for aphid resistance in two different cultivars of tomato. Three different constructs were investigated for their transformation efficiency in both the cultivars. A significant reduction in aphid fecundity was achieved by plant-mediated aphid-RNA silencing using the T-452 construct containing two Ace 1 fragments in the reverse and forward orientations. The use of this construct could dramatically decrease aphid population growth and lead to a substantial reduction in agricultural losses. These results obtained strongly suggest that the plant-mediated aphid-RNA silencing might be an effective way to develop disease resistance in various agricultural crops.

Author Contributions: Conceptualization, M.F. and T.C.; data curation, E.M.A.-S., A.A.A. and Q.S.; investigation, M.F. and E.M.A.-S.; methodology, M.F., E.M.A.-S., A.A.A., Q.S., H.A.A. and T.C.; project administration, M.F.; supervision, M.F., A.A.A., H.A.A. and T.C.; writing-original draft, M.F., E.M.A.-S. and A.A.A.; writing-review and editing, M.F., Q.S., H.A.A. and T.C.

Funding: This project was funded by the National Plan for Science, Technology and Innovation (MAARIFAH), King Abdul Aziz City for Science and Technology, Kingdom of Saudi Arabia, Award Number 12-BIO2919-02.

Conflicts of Interest: The authors declare no conflict of interest.

\section{References}

1. Alatar, A.A.; Faisal, M.; Abdel-Salam, E.M.; Canto, T.; Saquib, Q.; Javed, S.B.; El-Sheikh, M.A.; Al-Khedhairy, A.A. Efficient and reproducible in vitro regeneration of Solanum lycopersicum and assessment genetic uniformity using flow cytometry and SPAR methods. Saudi J. Biol. Sci. 2017, 24, 1430-1436. [CrossRef]

2. Hogenhout, S.A.; Ammar, E.-D.; Whitfield, A.E.; Redinbaugh, M.G. Insect Vector Interactions with Persistently Transmitted Viruses. Annu. Rev. Phytopathol. 2008, 46, 327-359. [CrossRef] [PubMed]

3. Moran, P.J.; Cheng, Y.; Cassell, J.L.; Thompson, G.A. Gene expression profiling of Arabidopsis thaliana in compatible plant-aphid interactions. Arch. Insect Biochem. Physiol. 2002, 51, 182-203. [CrossRef] [PubMed] 
4. Van Emden, H.F. Plant resistance to Myzus persicae induced by a plant regulator and measured by aphid relative growth rate. Entomol. Exp. Appl. 1969, 12, 125-131. [CrossRef]

5. Nabeshima, T.; Kozaki, T.; Tomita, T.; Kono, Y. An amino acid substitution on the second acetylcholinesterase in the pirimicarb-resistant strains of the peach potato aphid, Myzus Persicae. Biochem. Biophys. Res. Commun. 2003, 307, 15-22. [CrossRef]

6. McCormick, S.; Niedermeyer, J.; Fry, J.; Barnason, A.; Horsch, R.; Fraley, R. Leaf disc transformation of cultivated tomato (L. esculentum) using Agrobacterium tumefaciens. Plant Cell Rep. 1986, 5, 81-84. [CrossRef]

7. Vos, P.; Simons, G.; Jesse, T.; Wijbrandi, J.; Heinen, L.; Hogers, R.; Frijters, A.; Groenendijk, J.; Diergaarde, P.; Reijans, M.; et al. The tomato Mi-1 gene confers resistance to both root-knot nematodes and potato aphids. Nat. Biotechnol. 1998, 16, 1365-1369. [CrossRef]

8. Gal-On, A.; Wolf, D.; Wang, Y.; Faure, J.-E.; Pilowsky, M.; Zelcer, A. Transgenic resistance to cucumber mosaic virus in tomato: Blocking of long-distance movement of the virus in lines harboring a defective viral replicase gene. Phytopathology 1998, 88, 1101-1107. [CrossRef]

9. Wu, C.; Jia, L.; Goggin, F. The reliability of virus-induced gene silencing experiments using tobacco rattle virus in tomato is influenced by the size of the vector control. Mol. Plant Pathol. 2011, 12, 299-305. [CrossRef]

10. Fire, A.; Xu, S.; Montgomery, M.K.; Kostas, S.A.; Driver, S.E.; Mello, C.C. Potent and specific genetic interference by double-stranded RNA in Caenorhabditis elegans. Nature 1998, 391, 806-811. [CrossRef]

11. Hamilton, A.J.; Baulcombe, D.C. A Species of Small Antisense RNA in Posttranscriptional Gene Silencing in Plants. Science 1999, 286, 950. [CrossRef] [PubMed]

12. Mette, M.F.; Aufsatz, W.; van der Winden, J.; Matzke, M.A.; Matzke, A.J. Transcriptional silencing and promoter methylation triggered by double-stranded RNA. EMBO J. 2000, 19, 5194-5201. [CrossRef] [PubMed]

13. Kim, Y.H.; Soumaila Issa, M.; Cooper, A.M.W.; Zhu, K.Y. RNA interference: Applications and advances in insect toxicology and insect pest management. Pestic. Biochem. Physiol. 2015, 120, 109-117. [CrossRef]

14. Qi, T.; Guo, J.; Peng, H.; Liu, P.; Kang, Z.; Guo, J. Host-Induced Gene Silencing: A Powerful Strategy to Control Diseases of Wheat and Barley. Int. J. Mol. Sci. 2019, 20, 206. [CrossRef] [PubMed]

15. Pitino, M.; Hogenhout, S.A. Aphid Protein Effectors Promote Aphid Colonization in a Plant Species-Specific Manner. Mol. Plant Microbe Interact. 2012, 26, 130-139. [CrossRef] [PubMed]

16. Pitino, M.; Coleman, A.D.; Maffei, M.E.; Ridout, C.J.; Hogenhout, S.A. Silencing of Aphid Genes by dsRNA Feeding from Plants. PLoS ONE 2011, 6, e25709. [CrossRef] [PubMed]

17. Guo, H.; Song, X.; Wang, G.; Yang, K.; Wang, Y.; Niu, L.; Chen, X.; Fang, R. Plant-Generated Artificial Small RNAs Mediated Aphid Resistance. PLoS ONE 2014, 9, e97410. [CrossRef]

18. Tzin, V.; Yang, X.; Jing, X.; Zhang, K.; Jander, G.; Douglas, A.E. RNA interference against gut osmoregulatory genes in phloem-feeding insects. J. Insect Physiol. 2015, 79, 105-112. [CrossRef]

19. Mao, J.; Zeng, F. Plant-mediated RNAi of a gap gene-enhanced tobacco tolerance against the Myzus persicae. Transgenic Res. 2014, 23, 145-152. [CrossRef]

20. Bhatia, V.; Bhattacharya, R.; Uniyal, P.L.; Singh, R.; Niranjan, R.S. Host Generated siRNAs Attenuate Expression of Serine Protease Gene in Myzus persicae. PLoS ONE 2012, 7, e46343. [CrossRef]

21. Coleman, A.D.; Wouters, R.H.M.; Mugford, S.T.; Hogenhout, S.A. Persistence and transgenerational effect of plant-mediated RNAi in aphids. J. Exp. Bot. 2014, 66, 541-548. [CrossRef] [PubMed]

22. Xu, L.; Duan, X.; Lv, Y.; Zhang, X.; Nie, Z.; Xie, C.; Ni, Z.; Liang, R. Silencing of an aphid carboxylesterase gene by use of plant-mediated RNAi impairs Sitobion avenae tolerance of Phoxim insecticides. Transgenic Res. 2014, 23, 389-396. [CrossRef] [PubMed]

23. Abdellatef, E.; Will, T.; Koch, A.; Imani, J.; Vilcinskas, A.; Kogel, K.-H. Silencing the expression of the salivary sheath protein causes transgenerational feeding suppression in the aphid Sitobion avenae. Plant Biotechnol. J. 2015, 13, 849-857. [CrossRef] [PubMed]

24. Hua, C.; Zhao, J.-H.; Guo, H.-S. Trans-Kingdom RNA Silencing in Plant-Fungal Pathogen Interactions. Mol. Plant 2018, 11, 235-244. [CrossRef]

25. Canto-Pastor, A.; Santos, B.A.; Valli, A.A.; Summers, W.; Schornack, S.; Baulcombe, D.C. Enhanced resistance to bacterial and oomycete pathogens by short tandem target mimic RNAs in tomato. Proc. Natl. Acad. Sci. USA 2019, 116, 2755-2760. [CrossRef]

26. Canto, T.; Aranda, M.A.; Fereres, A. Climate change effects on physiology and population processes of hosts and vectors that influence the spread of hemipteran-borne plant viruses. Glob. Chang. Biol. 2009, 15, 1884-1894. [CrossRef] 
27. Short, J.M.; Fernandez, J.M.; Sorge, J.A.; Huse, W.D. Lambda ZAP: A bacteriophage lambda expression vector with in vivo excision properties. Nucleic Acids Res. 1988, 16, 7583-7600. [CrossRef]

28. Kerschen, A.; Napoli, C.A.; Jorgensen, R.A.; Müller, A.E. Effectiveness of RNA interference in transgenic plants. FEBS Lett. 2004, 566, 223-228. [CrossRef]

29. Murashige, T.; Skoog, F. A Revised Medium for Rapid Growth and Bio Assays with Tobacco Tissue Cultures. Physiol. Plant. 1962, 15, 473-497. [CrossRef]

30. Doyle, J.J.; Doyle, J.L. A rapid DNA isolation procedure for small quantities of fresh leaf tissue. Phytochem. Bull. 1987, 19, 11-15.

31. Sun, H.J.; Uchii, S.; Watanabe, S.; Ezura, H. A highly efficient transformation protocol for Micro-Tom, a model cultivar for tomato functional genomics. Plant Cell Physiol. 2006, 47, 426-431. [CrossRef] [PubMed]

32. Sun, S.; Kang, X.-P.; Xing, X.-J.; Xu, X.-Y.; Cheng, J.; Zheng, S.-W.; Xing, G.-M. Agrobacterium-mediated transformation of tomato (Lycopersicon esculentum L. cv. Hezuo 908) with improved efficiency. Biotechnol. Biotechnol. Equip. 2015, 29, 861-868. [CrossRef]

33. Malik, H.J.; Raza, A.; Amin, I.; Scheffler, J.A.; Scheffler, B.E.; Brown, J.K.; Mansoor, S. RNAi-mediated mortality of the whitefly through transgenic expression of double-stranded RNA homologous to acetylcholinesterase and ecdysone receptor in tobacco plants. Sci. Rep. 2016, 6, 38469. [CrossRef] [PubMed]

34. He, G.; Sun, Y.; Li, F. RNA interference of two acetylcholinesterase genes in Plutella xylostella reveals their different functions. Arch. Insect Biochem. Physiol. 2012, 79, 75-86. [CrossRef]

35. Kumar, M.; Gupta, G.P.; Rajam, M.V. Silencing of acetylcholinesterase gene of Helicoverpa armigera by siRNA affects larval growth and its life cycle. J. Insect Physiol. 2009, 55, 273-278. [CrossRef]

36. Satar, S.; Kersting, U.; Uygun, N. Effect of temperature on population parameters of Aphis gossypii Glover and Myzus persicae (Sulzer) (Homoptera: Aphididae) on pepper. J. Plant Dis. Prot. 2008, 115, 69-74. [CrossRef]

37. Chown, S.L.; Hoffmann, A.A.; Kristensen, T.N.; Angilletta, M.J., Jr.; Stenseth, N.C.; Pertoldi, C. Adapting to climate change: A perspective from evolutionary physiology. Clim. Res. 2010, 43, 3-15. [CrossRef]

38. Bauerfeind, S.S.; Fischer, K. Simulating climate change: Temperature extremes but not means diminish performance in a widespread butterfly. Popul. Ecol. 2014, 56, 239-250. [CrossRef]

39. Pörtner, H.O.; Bennett, A.F.; Bozinovic, F.; Clarke, A.; Lardies, M.A.; Lucassen, M.; Pelster, B.; Schiemer, F.; Stillman, J.H. Trade-Offs in Thermal Adaptation: The Need for a Molecular to Ecological Integration. Physiol. Biochem. Zool. 2006, 79, 295-313. [CrossRef]

40. Davis, J.A.; Radcliffe, E.B.; Ragsdale, D.W. Effects of High and Fluctuating Temperatures on Myzus persicae (Hemiptera: Aphididae). Environ. Entomol. 2006, 35, 1461-1468. [CrossRef]

41. Gillespie, D.R.; Nasreen, A.; Moffat, C.E.; Clarke, P.; Roitberg, B.D. Effects of simulated heat waves on an experimental community of pepper plants, green peach aphids and two parasitoid species. Oikos 2012, 121, 149-159. [CrossRef]

42. Zhao, F.; Zhang, W.; Hoffmann, A.A.; Ma, C.-S. Night warming on hot days produces novel impacts on development, survival and reproduction in a small arthropod. J. Anim. Ecol. 2014, 83, 769-778. [CrossRef] [PubMed]

43. Colinet, H.; Sinclair, B.J.; Vernon, P.; Renault, D. Insects in Fluctuating Thermal Environments. Annu. Rev. Entomol. 2015, 60, 123-140. [CrossRef] [PubMed]

44. Ghaedi, B.; Andrew, N.R. The physiological consequences of varied heat exposure events in adult Myzus persicae: A single prolonged exposure compared to repeated shorter exposures. PeerJ 2016, 4, e2290. [CrossRef]

(C) 2019 by the authors. Licensee MDPI, Basel, Switzerland. This article is an open access article distributed under the terms and conditions of the Creative Commons Attribution (CC BY) license (http://creativecommons.org/licenses/by/4.0/). 